\title{
When an Issue Becomes a Crisis An Investigation of Pre-crisis Communication through Annual Reports
}

\author{
Hatani, Faith
}

Document Version

Accepted author manuscript

Published in:

International Journal of Management Practice

DOI:

10.1504/IJMP.2019.100403

Publication date:

2019

License

Unspecified

Citation for published version (APA):

Hatani, F. (2019). When an Issue Becomes a Crisis: An Investigation of Pre-crisis Communication through Annual Reports. International Journal of Management Practice, 12(3), 283-300.

https://doi.org/10.1504/IJMP.2019.100403

Link to publication in CBS Research Portal

\section{General rights}

Copyright and moral rights for the publications made accessible in the public portal are retained by the authors and/or other copyright owners and it is a condition of accessing publications that users recognise and abide by the legal requirements associated with these rights.

Take down policy

If you believe that this document breaches copyright please contact us (research.lib@cbs.dk) providing details, and we will remove access to the work immediately and investigate your claim. 


\title{
When an Issue Becomes a Crisis: An Investigation of Pre- crisis Communication through Annual Reports
}

\author{
Faith Hatani \\ Journal article (Accepted manuscript*)
}

\begin{abstract}
Please cite this article as:
Hatani, F. (2019). When an Issue Becomes a Crisis: An Investigation of Pre-crisis Communication through Annual Reports. International Journal of Management Practice, 12(3), 283-300.

https://doi.org/10.1504/IJMP.2019.100403
\end{abstract}

\section{DOI: 10.1504/IJMP.2019.100403}

Uploaded to CBS Research Portal in accordance with the terms of Inderscience Publishers:

https://www.inderscience.com/mobile/inauthors/index.php?pid=74

* This version of the article has been accepted for publication and undergone full peer review but has not been through the copyediting, typesetting, pagination and proofreading process, which may lead to differences between this version and the publisher's final version AKA Version of Record.

Uploaded to CBS Research Portal: May २०२० 


\title{
When an issue becomes a crisis: an investigation of pre-crisis communication through annual reports
}

\author{
Faith Hatani \\ Department of International Economics, Government and Business, \\ Copenhagen Business School, \\ Porcelænshaven 24A, Frederiksberg 2000, Denmark \\ Email: fha.egb@cbs.dk
}

\begin{abstract}
Drawing on the issues management approach, this study investigates the pre-crisis communication of a multinational enterprise through its annual reports. Using Toyota's global recall crisis as an example, the study examines what a crisis-ridden firm actually focused on and the extent to which the firm communicated warning signs, before a crisis. By employing a leading-edge text analytics software, Leximancer, the study explores the narratives of the annual reports. It sheds light on a less-explored dimension of crisis communication and evidences a shortfall in Toyota's issues management. The findings show that Toyota's articulation of its core values, commitment to safety and customer-orientation subsided before the global recall crisis, despite the fact that some safety issues had surfaced by that time. The analysis highlights that there is a need for the company to conduct a more rigorous self-evaluation of its priorities through the process of outlining annual reports in a non/pre-crisis period.
\end{abstract}

Keywords: issues management; pre-crisis period; crisis communication; crisis management; retrospective case study; content analysis; Leximancer; annual report.

Reference to this paper should be made as follows: Hatani, F. (xxxx) 'When an issue becomes a crisis: an investigation of pre-crisis communication through annual reports', Int. J. Management Practice, Vol. X, No. Y, pp.xxx-xxx.

Biographical notes: Faith Hatani is an Associate Professor in International Business at the Copenhagen Business School, Denmark. She holds a PhD from the University of Cambridge, UK. Her research interests include strategies of multinational enterprises, internationalisation of the firm, global value chain, FDI, business ethics and economic development.

This paper is a revised and expanded version of a paper entitled 'When an issue becomes a crisis: an investigation of pre-crisis communication through annual reports' presented at the British Academy of Management, 'Corporate Governance' Conference, University of Leeds, UK, 11-12 June 2018.

\section{Introduction}

Crisis prevention is an integral part of a firm's strategy in today's turbulent business environment. As recent corporate crises of large firms reveal, it is essential for managers to detect and monitor warning signs and act on any impending crisis in order to prevent 
the crisis or minimise its impact (Ulmer et al., 2015). This area has been labelled 'issues management' (Chase, 1984). Issues management is a firm's deliberate effort to identify and participate in the resolution of issues that affect its operations (Arrington and Sawaya, 1984). Despite the importance of prevention, however, most of the notable works in the field of crisis management and crisis communication have tended to examine organisations' responses in the post-crisis period (Ulmer, 2001).

Thus, this study focuses on the pre-crisis communication of a multinational enterprise (MNE) through the narrative part of its annual reports. The narrative part can expose the firm's priorities and intended goals. A large MNE's annual reports are particularly useful for assessing its managerial focus, as they provide comprehensive explanations of the firm's strategic focus for a range of stakeholders across borders. The study analyses Toyota's annual reports, published around the time of its global recall crisis, which began in 2009. Toyota became the centre of media attention due to accidents involving, reportedly, malfunctioning 'sticky pedals' and following a large-scale recall globally. Because of the sensational media coverage against the world-leading carmaker, Toyota's recall crisis attracted scholarly attention in several fields, such as supply chain management (Kumar and Schmitz, 2011), supplier-buyer relations (Dyer and Chu, 2011), corporate reputation (Fan et al., 2013) and crisis management and response (Choi and Chung, 2013). However, no research has investigated how Toyota publicly communicated - or did not communicate - key issues involving its main business before the crisis.

Through a comparison of the company's narratives before and after the crisis, the paper investigates to what extent the crisis-ridden firm communicated symptoms of a crisis. The literature is drawn upon and analysed in an objective way using a leading-edge text analytics software, Leximancer. By doing so, the study sheds light on a black box what the company failed to perceive and communicate effectively - during the pre-crisis period.

\section{Issues management and crisis management}

Before a corporate crisis occurs, there are likely to be some issues that can be traced as their symptoms emerge (Kash and Darling, 1998). An issue is understood as a condition or pressure that could affect the organisation if it persists (Brown, 1979), whereas a 'crisis' is an acute incident that will disrupt the organisation's operations and potentially threatens all group members (Coombs and Holladay, 2006). Although issues and crises differ in definition (and accordingly there are two interrelated fields, i.e., crisis management and issues management), an issue and a crisis should not be separated in analysis since they are integral parts of the story (Jaques, 2007).

\subsection{Crisis as a process}

Issues management is "a process for forecasting potential situations and specific topics that have significant impact on the operations of the organisation" [Mahon and Cochran, (1991), p.159]. Weiss (2014, p.139) also defines issues management as 'a formal process' which is used to "anticipate and take appropriate action to respond to emerging trends, concerns, or issues that can affect an organisation and its stakeholders." Comfort (2007) argues that responding to an emergency requires the capacity to recognise the degree of 
emerging risk. It is vital for the firm to identify an issue properly and take sufficient appropriate action (Mahon and Cochran, 1991). As Kash and Darling (1998) point out, however, companies often fail to notice symptoms that are actually present in various aspects of their businesses. Although a crisis is an urgent, time-pressured situation, it does not necessarily happen suddenly, nor is it always unexpected (Kash and Darling, 1998). Furthermore, a crisis does not occur in complete isolation, but starts long before the triggering event (Roux-Dufort, 2007). Thus, the processual approach to crises is not only suitable but also imperative, enabling firms to pay more attention to the early stage of a crisis and alerting management to social, political and economic issues, thereby preventing or mitigating their impact (Kash and Darling, 1998). This involves prioritisation of the most important issue among several issues, which largely depends on organisational criteria (Mahon and Cochran, 1991).

While both crisis management and issues management underscore the process undertaken by an organisation along with a crisis, the pre-crisis and post-crisis phases have not been adequately consolidated in the literature and there has been a tendency that pre-crisis phases is overlooked in previous studies (Roux-Dufort, 2007). In the crisis literature, several distinct phases of a crisis have been identified. One classic model is Mitroff's (1988) five phases of crisis management, comprising:

a signal detection

b preparation/prevention

c containment/damage limitation

d recovery

e learning.

Yet, preparation and prevention require a sufficient understanding of how an issue may manifest (Barnes and Oloruntoba, 2005) and a signal can often be undetected by managers over time. Fink (1986) provides another model consisting of four stages; that is, the prodromal crisis stage, acute crisis stage, chronic crisis stage and crisis resolution stage. Fink's (1986) model acknowledges the importance of an early symptom in the prodromal stage, but still gives more weight to the crisis incident and the following post-crisis periods. It should be also noted that crisis situations are heterogeneous, so that there can be 'random' insights into the crisis management process. To address this, Coombs (1999) proposes a three-stage approach, which contains broad but imperative stages, namely, pre-crisis, crisis and post-crisis; this approach allows researchers to accommodate other process models and ideas.

While the process models are very relevant to approach crisis analysis, there is a need for additional research on a pre-crisis period to provide a more comprehensive picture of the origins and sources functions of a crisis along the crisis cycle (Jin et al., 2014). Hence, by incorporating Fink's (1986) idea of the 'prodromal stage' into Coombs' (1999) three generic stages, this study categorises the crisis process into four phases, i.e., the pre-crisis phase, the prodromal phase, the crisis phase and the post-crisis phase. First, the pre-crisis phase is a time when symptoms of a crisis are relatively weak. Second, the prodromal phase is a phase in which there are some alarming signs or fluxes in the internal and/or external organisational environment (Fink, 1986; Paraskevas, 2006). Third, the crisis phase is the acute time during which a crisis unfolds. Fourth, the 
organisation recovers and learns from a crisis in the post-crisis phase (Mitroff, 1988; Coombs, 1999). By putting in a prodromal phase as a sub-phase of the pre-crisis period, we look at the pre-crisis period in more detail.

\subsection{Pre and post-crisis communications}

In order to prevent a crisis, the study of issues management should be incorporated into the study of crisis communication as a long-term process (González-Herrero and Pratt, 1996). In fact, Sommerfeldt and Yang (2017) define issues management as a communication management. The importance of communication has been well documented in crisis analysis. For instance, Kash and Darling (1998) argue that effective use of communication is vital in dealing with any crisis. Penrose (2000) contends that effective communication should be a company's top priority at a time of crisis. Yet, similar to crisis management studies, crisis communication research has largely focused on the post-crisis stage (Ha and Boynton, 2014). While there is no doubt that communication during the crisis is vital, it is also important for a firm to communicate with the relevant public at the right time (Ha and Boynton, 2014). In other words, crisis communication needs to be performed not only during/after a crisis but also prior to it (Fearn-Banks, 1996).

An overarching goal of issues management is to identify an issue and organise the firm's expertise to address it in order to reduce risk, thereby creating opportunities that benefit the firm and its stakeholders (Tucker et al., 1993). Coombs and Holladay (2002) argue, as a part of their situational crisis communication theory (SCCT), that not doing enough to prevent an accident or a defective product from reaching the market is actually to place stakeholders at risk. Such a preventable crisis, which could be avoided through the organisation's responsible and attentive approach to an issue at an early stage, has the most negative impact on the firm's reputation (Coombs and Holladay, 2002; Claeys et al., 2010). Indeed, issues management contains an aspect of stakeholder management, in which managers ought to "communicate with stakeholders for the sake of communication” [Freeman, (2010), p.169].

Furthermore, Bowen and Heath (2005) suggest that issues management is a strategic information-processing system that entails issues communication by creating a productive discourse between the organisation and its stakeholders. As Cheney and Lair (2005, p.75) suggest, "organizational rhetoric has drawn attention to issues and concerns in contemporary organizational life with a focus on issues of persuasion and identification.” Hence, the firm needs to establish strong communication channels and demonstrate its positive value positions to stakeholders before a crisis occurs (Ulmer, 2001). In this regards, we can perceive that what managers said or did not say to stakeholders in the pre-crisis stage is likely to have an impact at a later time.

\subsection{What the annual report can tell us}

The corporate annual report is a useful source to retrospectively trace how a firm perceived and explained an emerging issue before a crisis set in. The retrospective studies enable the researcher to identify patterns in dynamic processes and a single-site case study can provide relatively high internal validity with a good chance to establish a link between cause and effect (Leonard-Barton, 1990). To approach what a firm communicated, an ideal way might be to trace every element spoken or written by the 
firm in question. Nonetheless, it is not practical to collect all communication outputs on various media. A problem with some types of online data (such as social media services) is that the users often generate unverified information (Aula, 2010). In addition, a collection of fragmented information does not necessarily generate a meaningful result. Thus, in order to conduct more focused investigation in a structured manner, the corporate annual report can be considered a relevant data source (Guthrie et al., 2004). More importantly, organisational messages consist not only of the interests that the organisation and its members speak, but also of the hidden interests that may not be expressed so explicitly (Henderson et al., 2015). Annual reports enable us to trace what the organisation told and did not tell.

A sceptical view (e.g., Michalisin, 2001) might suggest that firms often hire public relations agents to craft annual reports and that there is little motive for chief executive officers (CEOs) to create an accurate annual report. Subramanian et al. (1993) also argue that due to the firm's discretion in editing content, the annual report can be seen as a marketing communication tool to send a positive message about the firm to stakeholders. However, while these critical views have validity to some extent, the narrative part of the annual report still has credibility because of its proximity to the audited financial statements, so that gross discrepancies between performance and explanation can be detected quickly (Neu et al., 1998). Furthermore, Bowman (1984) maintains that most CEOs spend significant time outlining the contents of the report to reflect the company's performance thoroughly by addressing internal and external entities. In addition, given the global audiences' scrutiny, there should be no 'unusual puffery' on international issues in the annual report (Bowman, 1984). Compared to other media and advertisements, therefore, the annual report can be seen as a more trusted communication mechanism (Yuthas et al., 2002).

Since MNEs have a large number of audiences in mind, the contents of the annual report propose - even though they may not necessarily prove - the standards for the firm's action (Lentz and Tschirgi, 1963). While quantitative data in annual reports have been widely adopted in accounting studies, the narrative part of an annual report is equally important. It provides a rich description of topics that the firm focused on in a given year and what the firm intended to disseminate publicly. To this end, the annual report serves as a key communication vehicle of public relations (Guthrie and Petty, 2000). Through the annual report, MNEs can communicate their situation, performance and goals to a wide audience in a more complete and legitimate manner than through other communication media (White and Hanson, 2002).

In fact, the narrative part of the annual report is the crucial element that enables the firm to communicate its strategy and announce any desired change (Beattie et al., 2004; Santema et al., 2005). In compiling an annual report, the CEO and managers evaluate their company's activities every year and this yearly task intentionally and unintentionally forces them to signal what they regard as important (Neu et al., 1998). By doing so, the firm may "enlist societal discourses in the satisfaction of the demands of specific publics” [Neu et al., (1998), p.268], while reflecting its focus and priority in the annual report. Since the annual report encompasses all information regarding the firm, its contents can serve as a valuable data source for examining the patterns of the firm's causal reasoning (Guthrie and Petty, 2000). Thus, non-financial narrative information in the annual report can reveal what the firm focused on at a given time and the messages that the firm intended to convey through its annual report (Goh and Lim, 2004). Hence, it 
permits us to explore not only what was said, but also what was not said (Bowman, 1978).

\section{Methods}

\subsection{The case of Toyota's global recall crisis}

This study employs a narrative case study and adopts content analysis of annual reports. Using annual reports makes the analysis less subjective, free from memory error and personal bias, when obtaining reliable opinions and thoughts from practitioners is difficult (Ha and Riffe, 2015). The narrative materials used in this study are Toyota's annual reports over ten years between 2005 and 2014. Although Toyota's global recalls were concentrated between 2009 and 2011, we extend the period of time to be assessed because the evaluation of past narratives relative to later ones can indicate changes and effectiveness of communication at the later time (Segars and Kohut, 2001).

Generally speaking, the majority of firms publish their annual report at the end of the first quarter of the following year, by looking back at the last year and remarking on the action that caused the firm's performance. In Japan, where Toyota is headquartered, the fiscal year runs from 1 April to 31 March. Each of Toyota's annual report covers this fiscal period and is published in July.

First of all, we divided Toyota's annual reports published in the ten-year period into two distinct periods - that is, pre-crisis (2005-2009) and post-crisis (2010-2014) - to make a clear contrast between the two. Then, each period was further classified into two phases respectively - the pre-crisis and prodromal phases within the pre-crisis period and the crisis and post-crisis phases within the post-crisis period - in order for phase-by-phase analysis. Since the Toyota global recall crisis was mainly covered in two annual reports (2010 and 2011), we have set these two years as the crisis phase at the outset. Accordingly, two preceding years (2008 and 2009) are set as the prodromal phase to make the volume of the dataset comparable to that of the crisis phase, whereas the pre-crisis phase and the post-crisis phase comprise three years. This classification of the sample reports is reasonable because, by definition, the crisis phase and to a lesser extent the prodromal phase, are more acute than the pre-crisis and the post-crisis phases.

\subsection{Data analysis}

Content analysis involves classifying words and concepts in textual documents. Due to the rich information that annual reports can provide, some older studies of annual reports focus only on specific sections or small sub-units (e.g., Bettman and Weitz, 1983). However, such approaches have the limitation of generating only a partial picture of particular issues (Beattie et al., 2004). Thus, in line with more recent studies that used the narrative of the annual report (e.g., Beattie et al., 2004; Linsley and Shrives, 2006), we look at the entire narrative in Toyota's annual reports over the ten years to yield a holistic assessment. The study applied computer-assisted coding by using Leximancer, a lexicographic tool that analyses textual data through statistics-based algorithms (Crofts and Bisman, 2010). Although manual coding has some benefits (for instance, enabling more fine-tuned coding), it is commonly done into pre-defined categories, thereby being 
potentially subject to researcher bias. In contrast, Leximancer codes textual data algorithmically to discover the concepts within the data, thus avoiding coder bias.

Leximancer extracts and measures the frequency of concepts in source texts. When a certain concept has a strong presence, it makes up a 'theme'. Themes are higher hierarchies in the concept map that Leximancer generates; related concepts are clustered into a 'theme wheel' on the concept map (cf. Figure 1). Section 4 will first present a comparison between the pre-crisis period and the post-crisis period to grasp overall differences. We will then examine the presence of key concepts in each phase of the four-phase model described above.

\section{Findings}

\subsection{Overview: pre and post-crisis periods compared}

Figures 1(a) and 1(b) are concept maps that provide an overview of Toyota's annual reports in the pre-crisis period (2005-2009) and the post-crisis period (2010-2014). On each map, the years of the annual reports are tagged to concepts in aggregated theme wheels, indicating which annual report contributed most to a certain concept. Three basic indicators in the concept map should be noted:

1 the concepts in each theme wheel

2 the colour of the theme wheel

3 the position of a concept/wheel relative to other concepts/wheels on the map.

First, each theme wheel contains co-occurring concepts within it. If some concepts frequently appear together in a given annual report, they are displayed in close proximity to one another on the concept map. Second, the colour of each theme wheel indicates the importance of the theme. Following basic colour theory, the most important theme is shown in red. The red wheel is the 'hottest' theme and the second most important is orange; warmer colours indicate more prevalent concepts, cooler colours less prevalent (e.g., green, blue and purple come after red and orange, in order of importance). Third, the wheels' positions, such as closeness to/overlap with other theme wheels, suggest the connectedness between them.

As Figure 1 shows, the main (hottest) theme in the pre-crisis period was 'production' with a significant overlap with 'operations'. This is not surprising because it is essential for Toyota, a global manufacturer, to update information on how the company operated its production across borders. However, in the post-crisis period, this concept became just one of the concepts within the 'operations' theme. It suggests that the 'production' concept was more integrated into 'operations' after the recall crisis. In the pre-crisis period, the fifth most prevalent theme was 'plant', which is shown in a purple wheel in Figure 1(a). This reflects the fact that Toyota had some new factory start-ups between 2006 and 2007 across the world to meet global demand. As a tag from 2007 indicates, the theme of 'plant' in this period is largely contributed by the 2007 annual report that highlighted Toyota’s global expansion. 
8

F. Hatani

Table 1 Data profiles

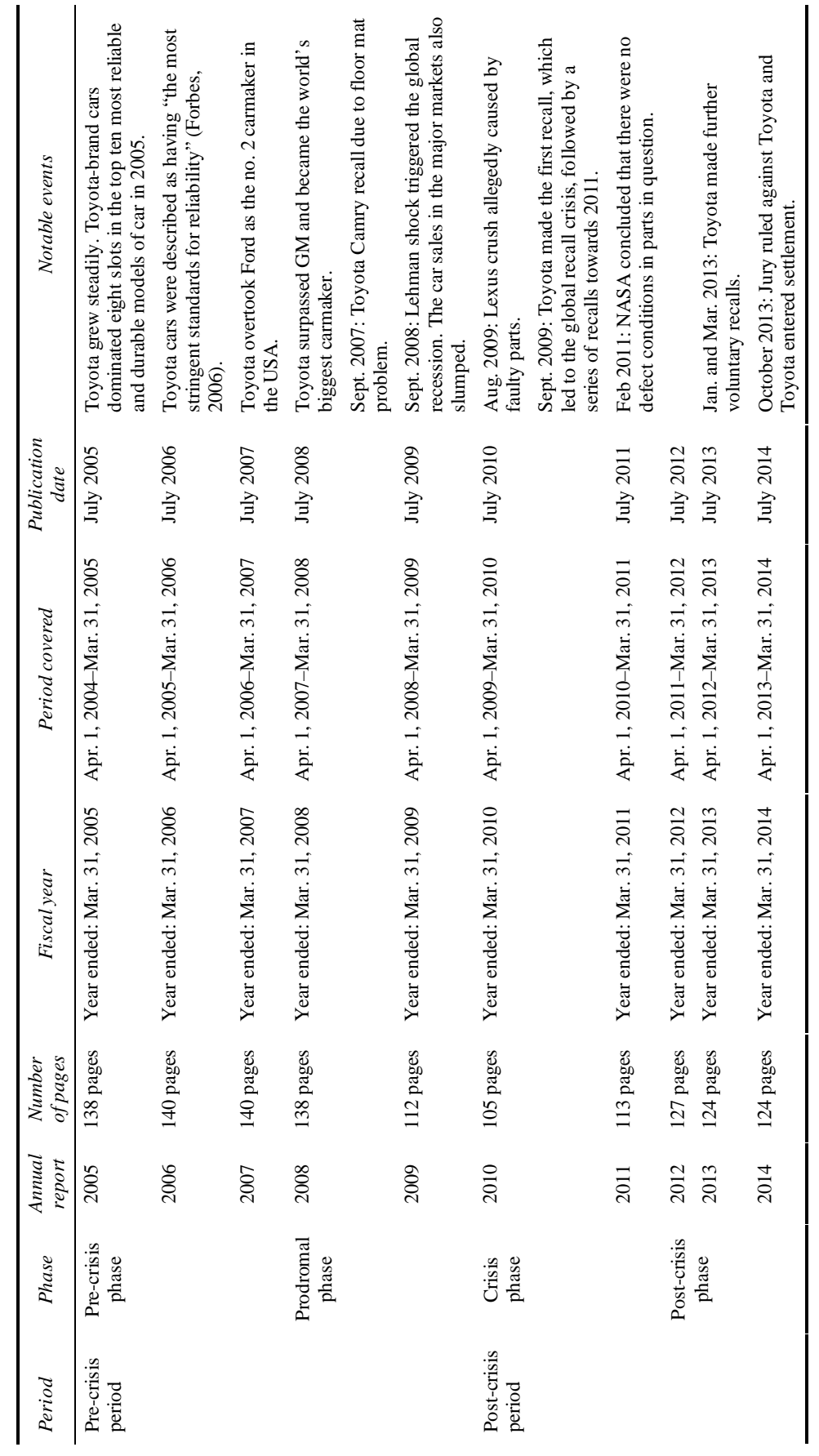


Figure 1 Concept maps of Toyota's annual reports, (a) pre-crisis period (2005-2009) (b) post-crisis period (2010-2014) (see online version for colours)

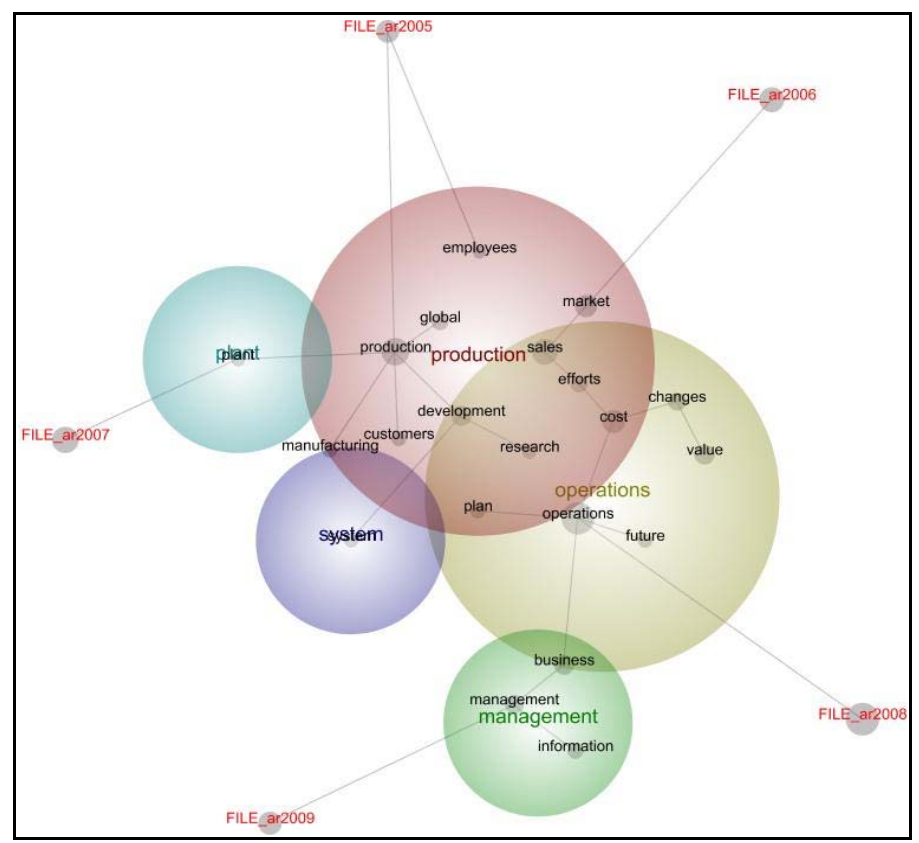

(a)

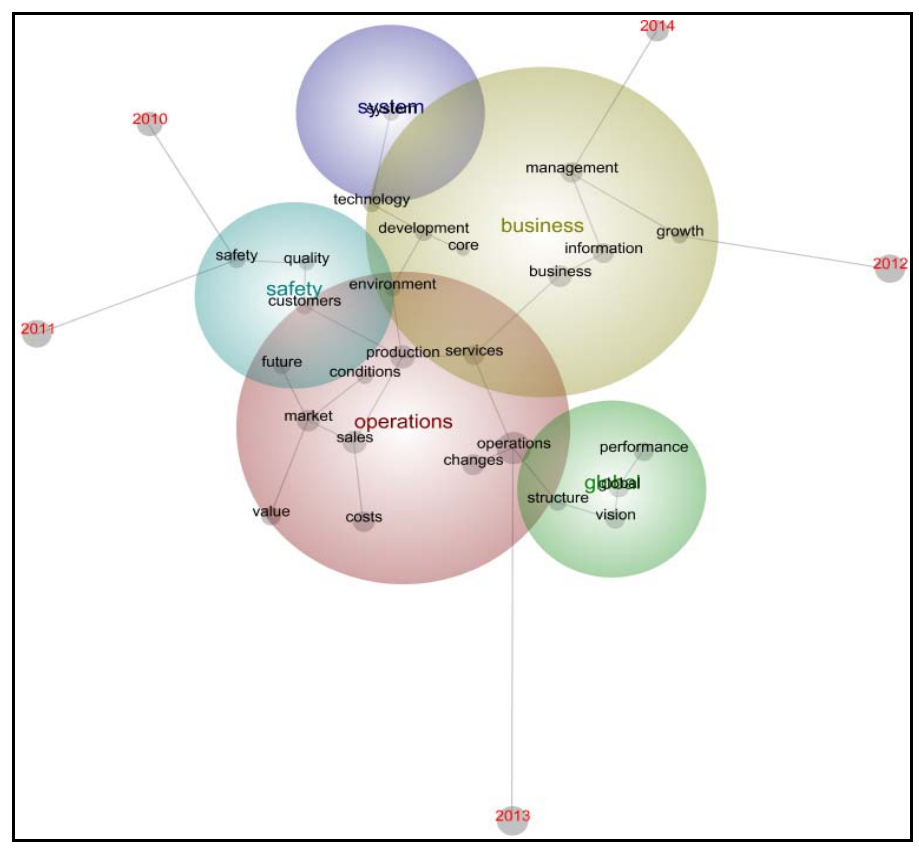

(b) 
It is notable that the concept of 'safety' does not appear as a theme or even as a main concept in the pre-crisis period; in contrast, the annual reports in the post-crisis period clearly exhibit 'safety' [shown as one of the theme wheels on the left-hand side on Figure 1(b)]. This is the foremost difference between the pre and post-crisis periods. ${ }^{1}$ It is also interesting to see how the concept of 'customers' was dealt with differently in the annual reports during the pre and post-crisis periods. In the pre versus post-crisis comparison in Figure 1, the 'customer' concept appears in the theme 'production' in the pre-crisis period, whereas 'customers' is positioned in the middle of the 'safety' theme in the post-crisis period.

\subsection{The four phases: what did each annual report prioritise?}

Now, we look at each phase more closely. Table 2 shows the most prevalent concepts in the top three themes in each phase. It is noteworthy that the most prevalent concept in the pre-crisis and prodromal phases is 'sales'. After the global recall, concepts such as 'customers', 'safety' and 'services' emerged as key concepts (a border is applied around the words on Table 2). After the global recall, it is no wonder that Toyota allocated more space in describing safety issues and related factors. Yet, the key point here is that before the crisis, these three concepts were not prevalent in Toyota's annual reports.

\subsubsection{The pre-crisis phase}

The annual reports in this phase mainly covered generic business concepts, such as 'sales', 'marketing', 'development' (regarding markets and products), 'global' and 'growth'. This reflects Toyota's ambition at that time to become the leading global carmaker. On the other hand, the concept of 'safety' was mentioned only 79 times in the annual reports between 2005 and 2007, ${ }^{2}$ and most of these are brief descriptions in sentences that listed several items; such as "demands with respect to quality, styling, reliability, safety and other features” (2007 annual report). Although 'safety' is supposed to be one of the prime focuses of a car manufacturer, it kept a relatively low profile in the reports in the pre-crisis phase.

\subsubsection{The prodromal phase}

In 2007, Toyota issued the model-specific minor recall of the Toyota 'Camry' in the USA, which fell into the period covered by the 2008 annual report, two years before the global recall crisis set in. Yet, the most prevalent theme in this phase was 'operations'. Key concepts in this phase are quite similar to those found in the pre-crisis phase. According to the lexical data, the theme of 'operations' was heavily contributed by the word 'operating ${ }^{3}$, which occurred frequently in relation to financial terms, for example "Toyota achieved new records in net revenues, operating income” (2008 annual report). In fact, the phrase 'operating income' appears more than 1,000 times in the annual reports of 2008 and 2009, whereas the frequency of the word 'safety' is just 61 (38 times in 2008 and 23 times in 2009). This evidences that in the prodromal phase, Toyota was heavily focused on its sales expansion and financial return to shareholders. This is rather surprising given that the Camry recall occurred during this phase. 
When an issue becomes a crisis

Table 2 Key concepts in Toyota's annual reports

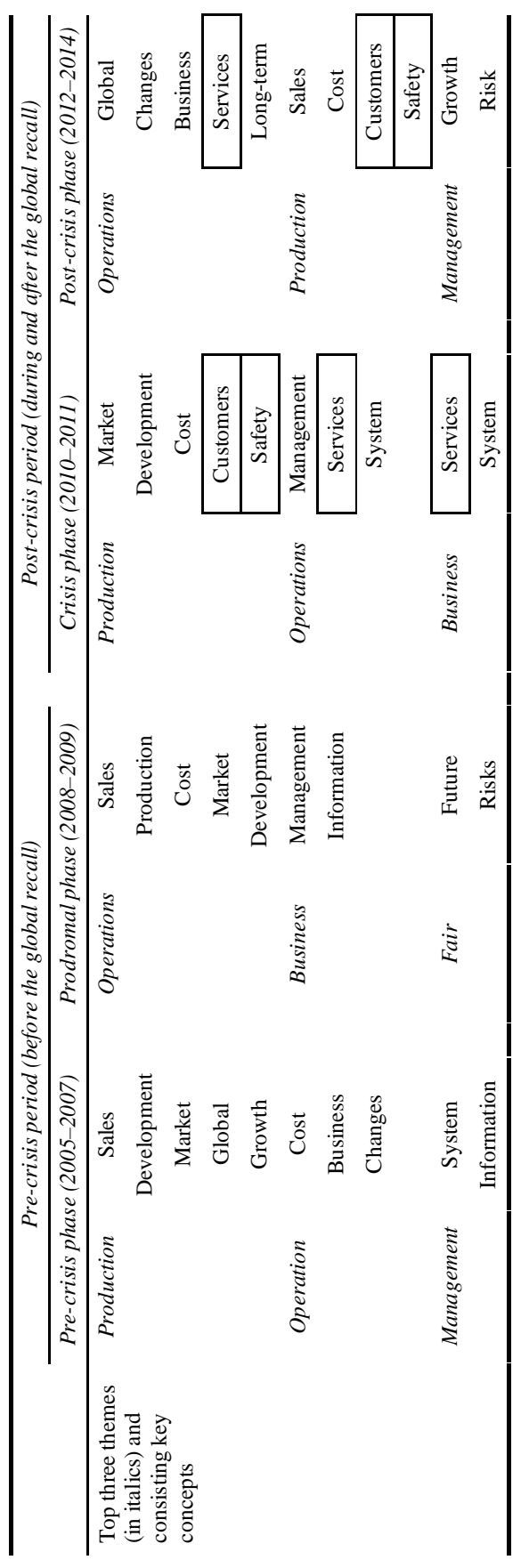




\subsubsection{The crisis phase}

This was the time when Toyota issued the large-scale global recall. Thus, unsurprisingly, the concepts of 'customer' and 'safety' appeared often in the 'production' theme in the annual reports during the crisis phase. It should also be noted that the concept of 'services' appears in the themes of 'operation' as well as 'business' in this phase. Although the narrative in Toyota's annual reports tended to focus on production management in the pre-crisis period, it appears that the global recall crisis induced the company to elaborate its service activities more substantially and communicate its renewed commitment to safety along with the customer-centred approach in the annual reports in the crisis phase.

\subsubsection{The post-crisis phase}

This is a recovery-and-learning phase. The annual reports at this time exhibit the concept of 'services' even more prevalently in the theme of 'operations'. Also, the concept of 'long-term' was mentioned frequently in this theme. The second theme of this phase, 'production', includes the concepts of 'customers' and 'safety' alongside 'sales' and 'cost'. It is also notable that the theme of 'management' in this phase contains 'growth' and 'risk' as key concepts. The post-crisis phase indicates that the annual report in this phase elaborated Toyota's approach in a more comprehensive manner.

\section{Discussion}

The study empirically shows interesting findings, especially regarding the pre-crisis period, which go beyond the scope of previous studies that looked mainly at Toyota's response in the post-crisis period. The findings have revealed that Toyota failed to prioritise some issues in its annual reports during the prodromal period. As shown above, the concepts of 'safety', 'customers' and 'services' have a weak presence in the pre-crisis annual reports. Of course, the weak presence of such concepts in the annual reports per se does not necessarily mean that Toyota utterly neglected these factors in practice. Yet, one of the main roles of the annual report is to send the firm's core message to stakeholders. The pre-crisis annual reports did not adequately articulate the importance of safety and customers.

\subsection{Failure to communicate core values}

Focusing on the two years in the prodromal phase, we now turn to a consideration of what contributed to Toyota's weakened focus on the pivotal concepts, such as 'safety' and 'customers', before the crisis. The prodromal phase was, in fact, the beginning of the global recession, triggered by the Lehman shock in September 2008, thereby intensifying the challenge to the automotive industry globally (Liker and Ogden, 2011). Around that time, Toyota conducted intensive and detailed analysis worldwide (Liker and Ogden, 2011) and its efforts are observable when we read the 2009 annual report. Nevertheless, it appears that Toyota was so heavily preoccupied with the global recession that it paid too much attention to macro-level market analysis, curtailing the focus on fundamental factors in its main business such as safety and customers. In fact, the President of Toyota 
publicly admitted, after the global recall crisis, that the company focused excessively on market share and profits, which might have caused quality problems in the production (Camuffo and Wilhelm, 2016). The company's weak attention to key issues is itself the early symptom of a problem. Toyota, which is usually famous for its customer-first philosophy, should have reassured its stakeholders - not only shareholders but also suppliers and employees - that customers were the centre of its business despite the market turmoil. Due to an overwhelming sense of adversity brought about by the global recession, however, Toyota failed to communicate its core values in the annual reports in the best possible fashion.

\subsection{The need for early detection of symptoms}

The narrative part of the annual report allows managers to select or omit events and to script their words to shape what the public knows about the organisation (Neu et al., 1998). First, therefore, the responsible persons in a corporation need to identify topics to be communicated among the various types of issues involved in the firm's business activities. As Pearson and Mitroff (1993) argue, an organisation's executives should prepare for the fullest range of crises by selecting at least one specific example from each type, since it is not certain which issue will develop into a crisis. The attentiveness to everyday business is essential for effective issues management because the inability to attend to symptoms of crises build up over time (Williams et al., 2017). In the case of Toyota's global recall, some media sources claim that Toyota was aware of the issue resulted in the recalls as early as 2004 (Bowen and Zheng, 2015). It is highly problematic if this was the case, because given the importance of monitoring signs of danger, the omission of safety and customer-centred approach in Toyota's annual reports can be evidence of the company's weakened interests in these key aspects of their business.

Second, it should be noted that the annual report is a comprehensive and regular publication that includes various practical and analytical messages that affect external and internal audiences (Cheney and Lair, 2005). Stakeholders, including employees and suppliers, who read the annual report can observe the company's commitment to its customers through the narrative it contains (Segars and Kohut, 2001). As Liker and Ogden (2011, p.225) maintain, "the clarity of its values and its culture is absolutely essential to enabling the inculcation of that culture across national boundaries." Yet, as the company grows bigger and operates globally, some foreign subsidiaries may not adhere to the company's basic creeds and this is exactly the situation which Toyota has been put into (Camuffo and Wilhelm, 2016). Large MNEs in particular need to communicate effectively because they have different types of suppliers and employees across borders, who may not know or understand the company's core values. Given that organisations are contexts of struggle between competing interests and their respective systems of representation (Mumby, 1993), it is indeed a demanding task to send a comprehensive yet clear message in the limited space in each annual report. Nonetheless, orientations to the core values of the firm should not be lessened.

Lastly, an implication for large firms, especially in the automotive industry, is the need for a renewed sense of moral responsibility to prevent and respond to a recall crisis (Bowen and Zheng, 2015). Recall crises might be inevitable because of the complex global production, more demand for sophisticated technologies and higher quality of safety (Wei et al., 2016; Bundy et al., 2017). Nevertheless, the firms need to be aware 
that a product recall can be a result of everyday operations and has cumulative effects on the firms themselves once it happens (Hsu and Lawrence, 2016). Although Toyota's global recall might be caused by a third party's technical error, the study shows that Toyota, the lead firm of a large supply chain, neglected a key task in its public communication in the pre-crisis period. When the company's core values - such as the concepts of 'safety' and 'customer' in the case of Toyota - subside in the firm's official message, it could fail to reassure employees and suppliers that the firm continually prioritises those core values.

It should be noted that the annual report is not only a means to disseminate information on the firm's performance; it can also be used to assure stakeholders of the firm's core values and to reassure the firm itself of those values in order to maintain the standards. A key aspect of issues management is its emphasis on organisation's strategic initiatives (Sommerfeldt and Yang, 2017). In other words, issues management is the executive function of strategic public relations (Bowen, 2005), which is intertwined with strategic communication management as a whole. Senior management should regard compiling annual reports as a vital self-evaluation process of the company's strategic focus to achieve this goal.

\section{Conclusions}

This study has revealed a crisis-ridden firm's weakened focus on its core values in the pre-crisis period, using the Toyota's global recall crisis as an example; the focus presented in its annual report apparently shifted from safety and customer-orientation towards sales-orientation just before the crisis. Although Toyota is known for its customer-centred corporate strategy, its references to 'safety' and 'customer' were less prevalent in the annual reports during the pre-crisis period. This finding highlights the importance of examining neglected factors - what was not said or focused on in the firm's corporate message - in the pre-crisis period, because the firm's lack of attention itself can be a risky issue that could progress to a visible crisis. Annual reports should be utilised as a more proactive self-evaluation tool of the company's strategic focus to assess its comprehensive communication with not only shareholders but also a wider group of stakeholders. The first step for successful issues management will be to listen to the wider public's concerns regarding various issues (Kitchin and Purcell, 2017). It is a process to foster mutual interests within the communities where the company operates (Heath and Palenchar, 2009).

The findings of this study also prompt us - stakeholders, the public in general and researchers alike - to read and utilise annual reports more rigorously to detect some symptoms of issues that the firm may have. In this regard, stakeholders should be part of issues management to prevent a crisis [Coombs, (2015), p.107], since they can together help organisations identify warning signs and mitigate risks (Bundy et al., 2017). Of course, it does not mean that narratives in annual reports fully explain every aspect of a firm's managerial focus and reveal signs of emerging issues. However, the firm needs to articulate its priority in annual reports since a firm's reputation is built through good communication with stakeholders (Coombs and Holladay, 2006) and stakeholders are in a position to check if the priority is properly put into practice. Indeed, words and actions must go hand in hand to realise effective crisis prevention. 
This study certainly has its limitations. Methodologically, it used a single crisis case of one MNE. While a single-case study is useful to grasp and present a cause-and-effect linkage, its generalisability is limited (Leonard-Barton, 1990). In order to provide a testable proposition, future research could take different methodological approaches such as longitudinal multiple case analysis, possibly using other types of digital data. Also, future research could expand the scope with a larger sample of data and conduct comparative analyses of the pre-crisis communication of different companies. Moreover, given that crisis management is a process, a longitudinal study covering a longer period of time would appear to be promising, because the results of the past do tell us something about the future (Santema and van de Rijt, 2001). Lastly, future research could utilise companies' communications in other forms, such as social networks and examine different interpretations and logics manifested by a firm versus the public's opinions about a specific issue. While the generalisability of Toyota's case may be limited, the study does contribute a new angle to issues management by identifying a vacuum in the case firm's issues management during the pre-crisis period. More research in this area will enable us to identify what organisations' narratives reveal in times of crisis.

\section{References}

Arrington, C. and Sawaya, R. (1984) 'Managing public affairs: Issues management in an uncertain environment', California Management Review, Vol. 25, No. 4, pp.148-160.

Aula, P. (2010) 'Social media, reputation risk and ambient publicity management', Strategy \& Leadership, Vol. 38, No. 6, pp.43-49.

Barnes, P. and Oloruntoba, R. (2005) 'Assurance of security in maritime supply chains: conceptual issues of vulnerability and crisis management', Journal of International Management, Vol. 11, No. 4, pp.519-540.

Beattie, V., McInnes, B. and Fearnley, S. (2004) 'A methodology for analysing and evaluating narratives in annual reports: a comprehensive descriptive profile and metrics for disclosure quality attributes', Accounting Forum, Vol. 28, No. 3, pp.205-236.

Bettman, J.R. and Weitz, B.A. (1983) 'Attributions in the board room: causal reasoning in corporate annual reports', Administrative Science Quarterly, Vol. 28, No. 2, pp.165-183.

Bowen, A. and Zheng, Y. (2015) 'Auto recall crisis, framing, and ethical response: Toyota's missteps’, Public Relations Review, Vol. 41, No. 1, pp.40-49.

Bowen, S.A. (2005) 'A practical model for ethical decision making in issues management and public relations', Journal of Public Relations Research, Vol. 17, No. 3, pp.191-216.

Bowen, S.A. and Heath, R.L. (2005) 'Issues management, systems, and rhetoric: exploring the distinction between ethical and legal guidelines at Enron', Journal of Public Affairs, Vol. 5, No. 2, pp.84-98.

Bowman, E.H. (1978) 'Strategy, annual reports, and alchemy', California Management Review, Vol. 20, No. 3, pp.64-71.

Bowman, E.H. (1984) 'Content analysis of annual reports for corporate strategy and risk', Strategic Management, Vol. 14, No. 1, pp.61-71.

Brown, J.K. (1979) This Business of Issues: Coping with the Company's Environments, Conference Board Report No. 758, Conference Board, New York, NY.

Bundy, J., Pfarrer, M.D., Short, C.E. and Coombs, W.T. (2017) 'Crises and crisis management: integration, interpretation, and research development', Journal of Management, Vol. 43, No. 6, pp.1661-1692. 
Camuffo, A. and Wilhelm, M. (2016) 'Complementarities and organizational (mis)fit: a retrospective analysis of the Toyota recall crisis', Journal of Organization Design, Vol. 5, No. 4, pp.1-13.

Chase, H.W. (1984) Issues Management: Origins of the Future, Issue Action Publications, Stamford, CT.

Cheney, G. and Lair, D.J. (2005) 'Theorizing about rhetoric and organizations: classical, interpretive, and critical aspects', in May, S. and Mumby, D.K. (Eds.): Engaging Organizational Theory \& Research: Multiple Perspectives, pp.55-84, Sage, Thousand Oaks, CA.

Choi, J. and Chung, W. (2013) 'Analysis of the interactive relationship between apology and product involvement in crisis communication: an experimental study on the Toyota recall crisis', Journal of Business and Technical Communication, Vol. 27, No. 1, pp.3-31.

Claeys, A-S., Cauberghe, V. and Vyncke, P. (2010) 'Restoring reputations in times of crisis: an experimental study of the situational crisis communication theory and the moderating effects of locus of control', Public Relations Review, Vol. 36, No. 3, pp.256-262.

Comfort, L.K. (2007) 'Crisis management in hindsight: cognition, communication, coordination, and control', Public Administration Review, Vol. 67, No. 1, pp.189-197.

Coombs, W.T. (1999) Ongoing Crisis Communication: Planning, Managing, and Responding, Sage, Thousand Oaks, CA.

Coombs, W.T. (2015) Ongoing Crisis Communication: Planning, Managing, and Responding, 4th ed., Sage, Thousand Oaks, CA.

Coombs, W.T. and Holladay, S.J. (2002) 'Helping crisis managers protect reputational assets: initial tests of the situational crisis communication theory', Management Communication Quarterly, Vol. 16, No. 2, pp.165-186.

Coombs, W.T. and Holladay, S.J. (2006) 'Unpacking the halo effect: reputation and crisis management', Journal of Communication Management, Vol. 10, No. 2, pp.123-137.

Crofts, K. and Bisman, J. (2010) 'Interrogating accountability: an illustration of the use of Leximancer software for qualitative data analysis', Qualitative Research in Accounting \& Management, Vol. 7, No. 2, pp.180-207.

Dyer, J. and Chu, W. (2011) 'The determinants of trust in supplier-automaker relations in the US, Japan, and Korea: a retrospective', Journal of International Business Studies, Vol. 42, No. 1, pp.28-34.

Fan, D., Geddes, D. and Flory, F. (2013) 'The Toyota recall crisis: media impact on Toyota's corporate brand reputation', Corporate Reputation Review, Vol. 16, No. 2, pp.99-117.

Fearn-Banks, K. (1996) Crisis Communication: A Casebook Approach, Lawrence Erlbaum Associates Publishers, Mahwah, NJ.

Fink, S. (1986) Crisis Management: Planning for the Inevitable, American Management Association, New York, NY.

Forbes (2006) The Most Reliable Cars 2006 [online] http://www.forbes.com/2006/04/20/reliablevehicles-japanese_cx_dl_0424feat.html (accessed 19 September 2015).

Freeman, R.E. (2010) Strategic Management: A Stakeholder Approach, Cambridge University Press, Cambridge, UK.

Goh, P.C. and Lim, K.P. (2004) 'Disclosing intellectual capital in company annual reports: evidence from Malaysia’, Journal of Intellectual Capital, Vol. 5, No. 3, pp.500-510.

González-Herrero, A. and Pratt, C.B. (1996) 'An integrated model for crisis-communications management', Journal of Public Relations Research, Vol. 8, No. 2, pp.79-105.

Guthrie, J. and Petty, R. (2000) 'Intellectual capital: Australian annual reporting practices', Journal of Intellectual Capital, Vol. 1, No. 3, pp.241-251.

Guthrie, J., Petty, R., Yongvanich, K. and Ricceri, F. (2004) 'Using content analysis as a research method to inquire into intellectual capital reporting', Journal of Intellectual Capital, Vol. 5, No. 2, pp.282-293. 
Ha, J.H. and Boynton, L. (2014) 'Has crisis communication been studied using an interdisciplinary approach? A 20-year content analysis of communication journals', International Journal of Strategic Communication, Vol. 8, No. 1, pp.29-44.

Ha, J.H. and Riffe, D. (2015) 'Crisis-related research in communication and business journals: an interdisciplinary review from 1992 to 2011', Public Relations Review, Vol. 41, No. 4, pp.569-578.

Heath, R.L. and Palenchar, M.J. (2009) Strategic Issues Management: Organizations and Public Policy Challenges, 2nd ed., Sage, Thousand Oaks, CA.

Henderson, A., Cheney, G. and Weaver, C.K. (2015) 'The role of employee identification and organizational identity in strategic communication and organizational issues management about genetic modification', International Journal of Business Communication, Vol. 52, No. 1, pp.12-41.

Hsu, L. and Lawrence, B. (2016) 'The role of social media and brand equity during a product recall crisis: a shareholder value perspective', International Journal of Research in Marketing, Vol. 33, No. 1, pp.59-77.

Jaques, T. (2007) 'Issue management and crisis management: an integrated, non-linear, relational construct', Public Relations Review, Vol. 33, No. 2, pp.147-157.

Jin, Y., Liu, B.F. and Austin L.L. (2014) 'Examining the role of social media in effective crisis management: the effects of crisis origin, information form, and source on publics' crisis responses’, Communication Research, Vol. 41, No. 1, pp.74-94.

Kash, T.J. and Darling, J.R. (1998) 'Crisis management: prevention, diagnosis and intervention', Leadership \& Organization Development Journal, Vol. 19, No. 4, pp.179-186.

Kitchin, P.J. and Purcell, P.A. (2017) 'Examining sport communications practitioners' approaches to issues management and crisis response in Northern Ireland', Public Relations Review, Vol. 43, No. 4, pp.661-670.

Kumar, S. and Schmitz, S. (2011) 'Managing recalls in a consumer product supply chain - root cause analysis and measures to mitigate risks', International Journal of Production Research, Vol. 49, No. 1, pp.235-253.

Lentz, A. and Tschirgi, H. (1963) 'The ethical content of annual reports', Journal of Business, Vol. 36, No. 4, pp.387-393.

Leonard-Barton, D. (1990) 'A dual methodology for case studies: synergistic use of a longitudinal single site with replicated multiple sites’, Organization Science, Vol. 1, No. 3, pp.248-266.

Liker, J. and Ogden, T.N. (2011) Toyota under Fire: Lessons for Turning Crisis into Opportunity, McGraw Hill, New York, NY.

Linsley, P.M. and Shrives, P.J. (2006) 'Risk reporting: a study of risk disclosures in the annual reports of UK companies', British Accounting Review, Vol. 38, No. 4, pp.387-404.

Mahon, J.F. and Cochran, P.L. (1991) 'Fire alarms and siren songs: the role of issues management in the prevention of, and response to, organizational crises', Organization \& Environment, Vol. 5, No. 2, pp.155-176.

Michalisin, M.D. (2001) 'Validity of annual report assertions about innovativeness: an empirical investigation', Journal of Business Research, Vol. 53, No. 3, pp.151-161.

Mitroff, I.I. (1988) 'Crisis management: cutting through the confusion', Sloan Management Review, Vol. 29, No. 2, pp.15-20.

Mumby, D.K. (1993) 'Critical organizational communication studies: the next 10 years', Communication Monographs, Vol. 60, No. 1, pp.18-25.

Neu, D., Warsame, H. and Pedwell, K. (1998) 'Managing public impressions: environmental disclosures in annual reports', Accounting, Organizations and Society, Vol. 23, No. 3, pp.265-282.

Paraskevas, A. (2006) 'Crisis management or crisis response system? A complexity science approach to organizational crises’, Management Decision, Vol. 44, No. 7, pp.892-907. 
Pearson, C.M. and Mitroff, I.I. (1993) 'From crisis prone to crisis prepared: a framework for crisis management', Academy of Management Executive, Vol. 7, No. 1, pp.48-59.

Penrose, J. (2000) 'The role of perception in crisis planning', Public Relations Review, Vol. 26, No. 2, pp.155-171.

Roux-Dufort, C. (2007) 'Is crisis management (only) a management of exceptions?', Journal of Contingencies and Crisis Management, Vol. 15, No. 2, pp.105-114.

Santema, S. and van de Rijt, J. (2001) 'Strategy disclosure in Dutch annual reports', European Management Journal, Vol. 19, No. 1, pp.101-108.

Santema, S., Hoekert, M., van de Rijt, J. and van Oijen, A. (2005) 'Strategy disclosure in annual reports across Europe: a study on differences between five countries', European Business Review, Vol. 17, No. 4, pp.352-366.

Segars, A.H. and Kohut, G.F. (2001) 'Strategic communication through the World Wide Web: an empirical model of effectiveness in the CEO's letter to shareholders', Journal of Management Studies, Vol. 38, No. 4, pp.535-556.

Sommerfeldt, E.J. and Yang, A. (2017) 'Relationship networks as strategic issues management: an issue-stage framework of social movement organization network strategies', Public Relations Review, Vol. 43, No. 4, pp.829-839.

Subramanian, R., Insley, R.G. and Blackwell, R.D. (1993) 'Performance and readability: a comparison of annual reports of profitable and unprofitable corporations', Journal of Business Communication, Vol. 30, No. 1, pp.49-61.

Tucker, K., Broom, G.M. and Caywood C.L. (1993) 'Managing issues acts as bridge to strategic planning', Public Relations Journal, Vol. 49, No. 11, pp.38-40.

Ulmer, R.R. (2001) 'Effective crisis management through established stakeholder relationships: Malden Mills as a case study', Management Communication Quarterly, Vol. 14, No. 4, pp.590-615.

Ulmer, R.R., Sellnow, T.L. and Seeger, M.W. (2015) Effective Crisis Communication: Moving from Crisis to Opportunity, Sage, Los Angeles, LA.

Wei, J., Zhao, M., Wang, F., Cheng, P. and Zhao, D. (2016) 'An empirical study of the Volkswagen crisis in China: customers' information processing and behavioral intentions', Risk Analysis, Vol. 36, No. 1, pp.114-129.

Weiss, J.W. (2014) Business Ethics: A Stakeholder and Issues Management Approach, Berrett-Koehler Publishers, San Francisco, CA.

White, R. and Hanson, D. (2002) 'Corporate self, corporate reputation and corporate annual reports: re-enrolling Goffman', Scandinavian Journal of Management, Vol. 18, No. 3, pp.285-301.

Williams, T.A., Gruber, D.A., Sutcliffe, K.M., Shepherd, D.A. and Zhao, E.Y. (2017) 'Organizational response to adversity: fusing crisis management and resilience research', Academy of Management Annals, Vol. 11, No. 2, pp.733-769.

Yuthas, K., Rogers, R. and Dillard, J.F. (2002) 'Communicative action and corporate annual reports’, Journal of Business Ethics, Vol. 41, No. 1, pp.141-157.

\section{Notes}

1 This does not mean that the term 'safety' was not mentioned at all in the pre-crisis annual reports, but that the word was less prevalent and had limited connectedness and co-occurrence with other concepts in relative terms, thereby not being ranked highly by the algorithm.

2 According to the log book that Leximancer generates when creating a map.

3 Same as Note 2. 